\title{
Determination of Optimum Male: Female Ratio and Salinity Level for Larval Production of Macrobrachium rosenbergii (De Man 1879) under Sri Lankan Conditions
}

\author{
R.M.G. Ratnayake ${ }^{*}$, T. Sivananthawerl ${ }^{1}$, C.N. Walpita ${ }^{2}$ and U. Edirisinghe ${ }^{3}$ \\ Postgraduate Institute of Agriculture \\ University of Peradeniya \\ Sri Lanka
}

\begin{abstract}
Aquaculture is the fastest food growing activity in the world food sector. The global aquaculture production increased 13 times, from 8.53 million tonnes in 1970 to 64.82 million tonnes in 2007. Total annual global production of all freshwater prawn species was nearly 460,000 tonnes with a value exceeding US \$1.8 billion in 2007. Main freshwater prawn species commercially cultured in the world is Macrobrachium rosenbergii, Experiments were conducted at Brackish Water Prawn Breeding Station Pambala, Chilaw. First experiment was conducted to determine the suitable male and female ratio for Machrobrachium rosenbergii under Sri Lankan hatchery conditions. In this experiment males and females in 1:10,1:8, and 1:5, 1:3 ratios were cultured under artificial conditions in the hatchery. Three cement tanks $(8 \times 6 \times 1 \mathrm{~m})$ each separated into 4 parts by using plastic mesh frames were used. Each replicate had one blue clawed male and the experiment was repeated. Results revealed that 1:5 ratio gave significantly higher $(P<0.05)$ larvae, while in 1:10 ratio both eggs and larvae were in minimum numbers. The second experiment was conducted to determine the optimum salinity level for spawning of gravid females under Sri Lankan conditions. For this experiment, four fiber glass tanks each of $1000 \mathrm{~L}$ having two gravid females were used. Salinity was kept at 4, 5, 6, and 7 ppt and a constant temperature of $28^{\circ} \mathrm{C}$ was maintained. Experiment was repeated three times. Results revealed that $5 \mathrm{ppt}$ salinity gave the optimum conditions. These results could be used to obtain higher production of $\underline{M}$. rosenbergii seeds under Sri Lankan conditions.
\end{abstract}

Key Words: Macrobrachium rosenbergii, Male: female ratio, Salinity level.

\section{INTRODUCTION}

The giant freshwater prawn (Macrobrachium rosenbergii (De Man, 1879) is one of the most economically important species of prawns in the world. World aquaculture production of Macrobrachium rosenbergii increased to 118,501 tonnes, having a value US $\$ 410$ million in 2000. Total annual global production of all freshwater prawn species was nearly 460000 tons with a value exceeding US \$ 1.86 billion, in 2007. The People's Republic of China is the largest freshwater prawn producer in the world. Fresh water prawns have been reared in captivity, either through introducing wild juveniles or by trapping them, along with other crustaceans and fish in tidal ponds and paddy fields in Indian sub-continent (Wickins, 1976).

To whom correspondence should be addressed: r.mgratnayake@yahoo.com Department of Crop Science, Faculty of Agriculture, University of Peradeniya, Sri Lanka Department of Livestock Production, Faculty of Agriculture, Sabaragamuwa University of Sri Lanka Department of Animal Science, Faculty of Agriculture, University of Peradeniya, Sri Lanka 
However, modern aquaculture of this species has its origin in early 1960s. Ling (1977) and Ling and Costello (1979) reported that rearing of freshwater prawn larvae required brackish water conditions for survival. Adult prawns living totally in fresh water and streams have been collected from $160 \mathrm{~km}$ distance from the sea. The distribution of natural stocks of this species in Sri Lanka is abundant and its exploitation from the wild is in the increase (Samarasinghe, 1983). Expansion of the Macrobrachium rosenbergii culture in Sri Lanka is limited mainly due to lack of prawn seeds (4.1 million prawn seeds were produced in 2008). Therefore, good breeding techniques have to be developed under hatchery management conditions and upgrading of prawn seed production is essential in increasing freshwater prawn production in the country. Optimum sex ratio for maximum oviposition in Macrobrachium rosenbergii, Malecha (1983) suggested a ratio of 1: 4, 1:5, while Verghese et al. (1992) recommended 1:3, 1:4 or 1:5, and Sureshkumar and Kuroup (1998) suggested a 1: 4 male: female ratio. Consequently, based on these results for Sri Lankan hatchery conditions 1:3 1:5 1:8 male:female ratios were recommended. Freshwater prawn culture becomes more popular in the inland fisheries sector today. Therefore, development of mass scale seed production techniques is very important for popularizing freshwater prawn production in Sri Lanka. The objective of this study was to determine a suitable male: female ratio and optimum salinity level for spawning and hatching of eggs under Sri Lankan hatchery conditions.

\section{MATERIALS AND METHODS}

Experiments were conducted at Brackish Water Prawn Breeding Center, Pambala, Chilaw. Three cement tanks $(6 \mathrm{~m} \mathrm{x} 4 \mathrm{~m} 1 \mathrm{~m})$ were partitioned into four equal parts, by using plastic mesh and wooden frames, in order to prevent movement of prawn from one area to the other. Same water quality parameters were maintained in each replicate. Feed was supplied for the broodstock at $5 \%$ of body weight and two times per day. Temperature and $\mathrm{pH}$ were maintained at $28-30^{\circ} \mathrm{C}$, and 7.5-8.0 ranges, respectively. Ammonia level was maintained at less than $0.6 \mathrm{mg} / \mathrm{L}$ level during the 21 day culture period by supplying running water. To the four replicates of each treatment, randomly stocked one blue clawed male, (TL means 280 $\mathrm{mm}$.) and female (Fig. 1).

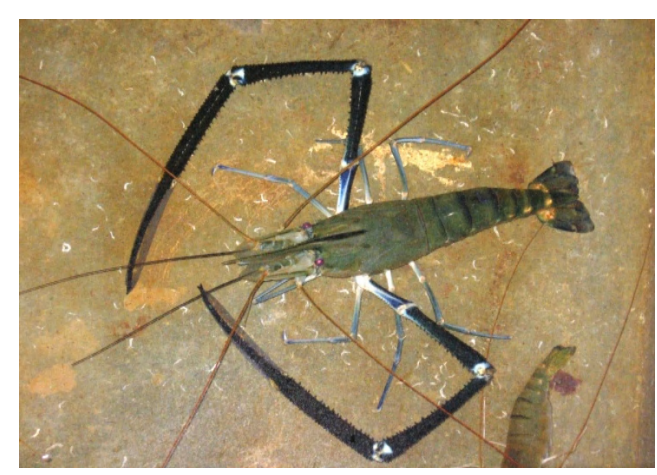

(a)

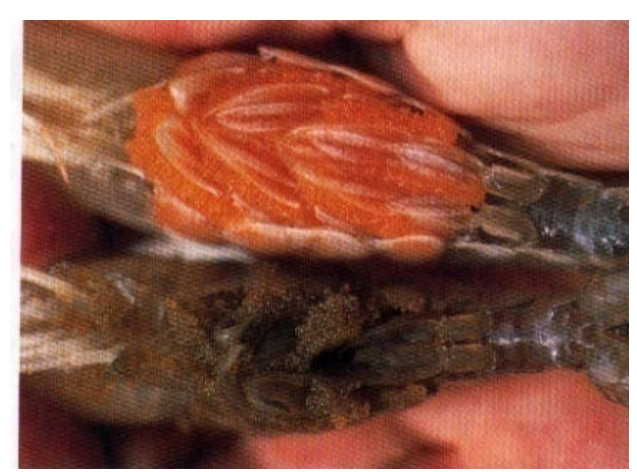

(b)

Fig. 1. Blue clawed male (a) and Gravid female (b)

Mean total length in 1:10, 1:8, 1:5, 1:3 ratios, (TL for male $280 \mathrm{~mm}$, and female $225 \mathrm{~mm}$ ). Experiment was performed for two culture cycles. Colour of the egg, in each gravid female 
was observed. Gravid females were harvested after 21 days and the weight of each prawn, total length and egg weight were obtained. The second experiment was to determine suitable salinity level for gravid females to spawn. In this experiment, four fiber glass tanks $1000 \mathrm{~L}$ each and salinity levels of 4, 5, 6 and $7 \mathrm{ppt}$ were maintained. Each treatment had six replicates. Temperature was maintained at $28^{\circ} \mathrm{C}$ using heaters (Model: 66, IMP.GAL.300W, Automatic). Salinity was measured by using a refractometer (type Milwaukee), $\mathrm{pH}$ measured using an electronic $\mathrm{pH}$ meter and ammonia by using a test-kit (Hatch Test Kit, FF-IA,). A completely randomized design was used for the second experiment. Logistic linear regression model was used to evaluate the hatching probabilities of the different male : female ratios. ANOVA were used for the mean separation of treatments, body weight and eggs weight of the prawns.

\section{RESULTS AND DISCUSSION}

\section{Experiment 1}

Water quality parameters in the treatments always ranged between the optimum values (Table 1).

Table 1. Water quality parameters measured (Experiment 1)

\begin{tabular}{|c|c|c|}
\hline Parameter & Mean \pm SE & Range \\
\hline Temperature(water) $\left({ }^{\circ} \mathrm{C}\right)$ & $28.7 \pm 0.048$ & $28-31$ \\
\hline Temperature (air ) $\left({ }^{\circ} \mathrm{C}\right)$ & $29.1 \pm 0.044$ & $28-32$ \\
\hline $\mathrm{pH}$ & $7.8 \pm 0.048$ & $7.0-8.5$ \\
\hline $\mathrm{DO}(\mathrm{mg} / \mathrm{L})$ & $6.06 \pm 0.047$ & $5.0-7.0$ \\
\hline Hardness $\mathrm{CaCO}_{3}(\mathrm{mg} / \mathrm{L})$ & $87.08 \pm 1.018$ & $50-100$ \\
\hline Ammonia $(\mathrm{mg} / \mathrm{L})$ & $0.46 \pm 0.036$ & $<0.5$ \\
\hline
\end{tabular}

Ammonia concentration was always maintained below $0.5 \mathrm{mg} / \mathrm{L}$ by having a running water system. It was essential since $M$ rosenbergii was fed with highly protenacious diet, which consisted of oyster mussels, fish and squids. New and Valenti (2000) have also recommended a highly protenacious diet to be given two times a day. New and Singholka (1985) have indicated that $\mathrm{pH}$ between 7- 8.5 and temperature between $28-32{ }^{\circ} \mathrm{C}$ should be maintained in the hatchery. They have also recommended that total hardness should be less than $100 \mathrm{mg} / \mathrm{L} \mathrm{CaCO}_{3}$ in the water. When 1:10 mal:female ratio was used, the number of eggs and larvae was found to be minimum $(13575 \pm 24)$. A significant difference $(\mathrm{p}<0.05)$ was observed between 1:8 and 1:3 ratios (Table 2).

Table 2. Number of eggs and larvae production (Experiment I)

\begin{tabular}{lcccc}
\hline Treatment & Quantity of eggs & $\begin{array}{c}\text { Weight of the } \\
\text { eggs (g) SE }\end{array}$ & $\begin{array}{c}\text { Larvae } \\
\text { numbers }\end{array}$ & $\begin{array}{c}\text { Total Length of } \\
\text { Female (cm) SE }\end{array}$ \\
\hline $1: 10$ & $24171^{\mathrm{b}} \pm 32$ & $13.5 \pm 0.76$ & $13575 \pm 24$ & $22.0 \pm 0.96$ \\
$1: 8$ & $25636^{\mathrm{b}} \pm 26$ & $15.5 \pm 0.61$ & $17595 \pm 20$ & $23.6 \pm 0.73$ \\
$1: 5$ & $34294^{\mathrm{a}} \pm 19$ & $19.1 \pm 0.45$ & $24427 \pm 16$ & $23.0 \pm 0.50$ \\
$1: 3$ & $26280^{\mathrm{b}} \pm 27$ & $20.0 \pm 0.63$ & $16509 \pm 21$ & $22.6 \pm 0.78$ \\
\hline
\end{tabular}

$\left({ }^{\mathrm{a}, \mathrm{b}}\right.$ values are significantly different $(\mathrm{p}<0.05)$. 
According to results, a significant difference $(\mathrm{P}<0.05)$ was observed among the four treatments with respect to total eggs laid (Table 2). Varghese et al. (1992) recommended a sex ratio between 1:375,-1:4.75 for maximum oviposition. Malecha (1983) has suggested 1:4 - 1:5 while Sureshkumar and Kurup (1998) have recommended 1:4 for optimum oviposition and hatching.

New and Singholka (1985), observed that a female $M$. rosenbergii can lay between 80,000 to 100,000 eggs per spawning when they are fully matured. In contrast, in this experiment the number of eggs spawned ranged between 24,171 and 34,294. New and Singholka (1985) have indicated that when $M$. rosenbergii breed for the first time, number of eggs ranged between 5,000 to 20,000. Therefore, prawns used in this experiment cannot be first brooders. Based on the results (Table 2), 1:5 would be the best combination of the male: female ratio to get highest larvae $(24427 \pm 16)$. However, the male: female ratio of 1:10 was found to be yield the lowest number of larvae among the treatments used (13575 \pm 24$)$.

\section{Experiment - (2)}

Water quality parameters were maintained under optimum conditions in Experiment 2 by having a running water system. Temperature was kept at $28^{\circ} \mathrm{C}$ by using heaters. Continuous aeration was also provided (Table 3 ).

Table 3. Water quality parameters in Experiment 2.

\begin{tabular}{lccc}
\hline Parameter & Unit & Mean \pm SE & Range \\
\hline Temperature (water) & ${ }^{\circ} \mathrm{C}$ & $28.0 \pm 0$ & $28-31$ \\
pH & - & $7.8 \pm 0.05$ & $7.0-8.5$ \\
DO & $\mathrm{mg} / \mathrm{L}$ & $6.13 \pm 0.04$ & $5.0-7.0$ \\
Hardness & $\mathrm{CaCO}_{3} \mathrm{mg} / \mathrm{L}$ & $86.11 \pm 1.27$ & $50-100$ \\
Ammonia & $\mathrm{mg} / \mathrm{L}$ & $0.43 \pm 0.03$ & $<0.5$ \\
\hline
\end{tabular}

Adult prawns were tolerant to a wide temperature range of $18-34{ }^{\circ} \mathrm{C}$ (New \& Valenti, 2000). New \& Singholka (1985) indicated that a pH between $7.0-8.5$ and temperature of $28-31^{\circ} \mathrm{C}$ could be maintained in a hatchery. They also recommended a hardness level of less than $100 \mathrm{mg} / \mathrm{L} \mathrm{CaCO} 3$ in the hatchery.

Table 4. Numbers of eggs and larvae produced in different salinities

\begin{tabular}{lcccc}
\hline $\begin{array}{l}\text { Salinity Level } \\
\text { (ppt) }\end{array}$ & Mean Egg No. & $\begin{array}{c}\text { Egg weight } \\
\text { (g) }\end{array}$ & No of Larvae & $\begin{array}{c}\text { Total length } \\
\text { (cm) }\end{array}$ \\
\hline 4 & $24360 \pm 16$ & $13.6 \pm 1.15$ & $1500 \pm 10$ & $22.5 \quad \pm 0.60$ \\
5 & $24300 \pm 23$ & $13.5 \pm 0.53$ & $17830 \pm 20$ & $22.2 \pm 0.66$ \\
6 & $24709 \pm 23$ & $13.7 \pm 0.53$ & $17052 \pm 19$ & $21.1 \pm 0.69$ \\
7 & $27600 \pm 24$ & $15.3 \pm 0.57$ & $4258 \pm 19$ & $22.4 \quad \pm 0.69$ \\
\hline
\end{tabular}

Results of Experiment 2 revealed that a salinity level of 5 ppt and 6 ppt provided optimums conditions for spawning and hatching (Table .4). The number of eggs spawned did not show a significant $(\mathrm{p}>0.05)$ difference (4ppt, 5ppt, 6ppt, and $7 \mathrm{ppt})$ among all the treatments (Table 3), indicating that salinity level does not have a significant effect on spawning. However, a significant difference $(\mathrm{p}<0.05)$ was observed between the numbers of larvae produced in the four treatments (Table 4 ). 
Salinity of 4 ppt produced few larvae, while at 7 ppt larval production was less than $5 \mathrm{ppt}$ and 6 ppt levels. According to New \& Valenti (2000), hatching occurs naturally under estuarine conditions and egg hatchability is higher in brackish water than in freshwater. Caluwe et al. (1995) reported that a combination of $6 \mathrm{ppt}$ salinity with temperature of 26 to $28^{\circ} \mathrm{C}$ is optimal for the incubation of M. rosenbergii eggs. However, Gomez (1987), observed that temperatures above $30^{\circ} \mathrm{C}$ levels causes problems due to development of protozoa and other microorganisms. According to the results, a male: female ratio of 1:5 and a salinity level of 5-6 ppt provides the optimum conditions for spawning and hatching of $M$. rosenbergii eggs under Sri Lankan hatchery conditions.

\section{CONCLUSION}

Based on the findings of this study, male: female ratio of 1:5 and a salinity level of 5-6 ppt provide the optimum conditions for spawning and hatching of $M$. rosenbergii eggs under Sri Lankan hatchery conditions. Therefore, these results will be important for the mass scale prawn seed production in the country. Moreover, further research is needed in breeding for the development of freshwater prawn culture sector in Sri Lanka.

\section{REFERENCES}

Cauwe, J. Korkor, A.M.E. Lavens, P. and Sorgeloos, P. (1995). Invitro hatching of Macrobrachium rosenbergii eggs: optimisation of environmental parameters. pp.83-86. In: Lavens, P. Jaspers, E. and Roelants, I. (Ed.) Larvi 95 Fish and Shellfish Larviculture Symposium, 3-7 september 1995, European Aquaculture Society, Ghent, Belgium

Gomez Diaz, G.,(1987). Effect of environmental embryonic development on larval development of Macrobrachium rosenbergii. Experimental Marine Biology and Ecology. $114,33-47$.

Ling, S.W. (1977). Aquaculture in Southeast Asia A Historical Overview, University of Washington press, Seattle, WA. pp.11-42.

Ling, S.W. and Costello, T.J. (1979). The Culture of freshwater prawn a review, pp. 299304, In: Pillary,T.V.R., Dill,W.A. (Ed.) Backwell Science, Oxford, London, UK..

Malecha,S.R. (1983). Commercial seed production of the freshwater prawn, Macrobrachium rosenbergii, in Hawaii. In CRC Handbook of Mariculture, Vol. 1 pp. 205-230. In: McVey,J.P. and Moore, J.R. (Ed.) CRC Press, Boca, Raton, FL.

New,M.B. and Singholka, S. (1985). Freshwater prawn farming A manual for the culture of Macrobrachium rosenbergii FAO Fisheries Technical paper 225 Revision 1 pp.10- 19.

New,M.B. and Valenti, W.C. (2000). Freshwater prawn culture, the farming of Macrobrachium rosenbergii . Backwell Science Ltd, Oseny mead, Oxford London, pp.26 45.

Samarasinghe,R.P. (1983) Breeding trials on the giant freshwater prawn in Sri Lanka, Journal of Inland Fisheries . 2, 143-149. 
Sureshkumar,S and Kurup,B.M. (1998). Reproductive activity of male morphotypes of Macrobrachium (De Man) and their performance in broodstock rearing and Larval reproduction. Journal of Aquaculture in the tropics 13, 87-94.

Varghese, A.G. Muthuraman, .A.L and Gopakumar,G. (1992). Sex-ratios in broodstock rearing of the giant prawn, Macrobrachium rosenbergii (De Man) a critical factors for oviposition and larval production., pp. 12-14, In: Silas, E.G .(Ed.) In Freshwater Prawns, Proceeding Kerala Aquaculture University, Thrissur, India.

Wickins, J.F. (1976). Prawn breeding and culture in Oceanography and Marine Biology:: Vol. 14, pp. 435-507, In: Baranes,H. (Ed.) An Annual Review, Aberdeen University press, Aberdeen, UK. 